\title{
Constraints in Adoption of Post Harvest Technologies in Maize Crop Faced by Farm Families of Udaipur and Chittorgarh District of Rajasthan, India
}

\author{
Chamandeep Kaur ${ }^{1}$, Dhriti Solanki ${ }^{2}$ and L. R. Choudhary ${ }^{3 *}$ \\ ${ }^{1}$ Department of Home Science, KVK Sawai Madhopur, (Raj), India \\ ${ }^{2}$ Department of HECM, College of H.Sc, MPUAT, Udaipur, (Raj), India \\ ${ }^{3}$ Department of Agriculture Extension, KVK Gudamalani, Barmer, (Raj), India \\ *Corresponding author
}

\section{A B S T R A C T}

\begin{tabular}{|l|}
\hline Ke y w or d s \\
Cooling, Cleaning, \\
$\begin{array}{l}\text { Sorting, Packing, } \\
\text { Large-scale, } \\
\text { Sophisticated, } \\
\text { Mechanised facility }\end{array}$ \\
\hline Article Info \\
\hline $\begin{array}{l}\text { Accepted: } \\
\text { 07 November } 2019 \\
\text { Available Online: } \\
\text { 10 December } 2019\end{array}$ \\
\hline
\end{tabular}

\section{Introduction}

In agriculture postharvest handling is the stage of crop production immediately following harvest, including cooling, cleaning, sorting and packing. The instant a crop is removed from the ground, or separated from its parent plant, it begins to deteriorate. Postharvest treatment largely determines final quality, whether a crop is sold for fresh consumption, or used as an ingredient in a processed food product. The most important goals of postharvest handling are keeping the product cool, to avoid moisture loss and slow down undesirable chemical changes, and avoiding physical damage such as bruising, to delay 
spoilage. ${ }^{[1][2]}$ Sanitation is also an important factor, to reduce the possibility of pathogens that could be carried by fresh produce, for example, as residue from contaminated washing water. After the field, post-harvest processing is usually continued in a packing house. This can be a simple shed, providing shade and running water, or a large-scale, sophisticated, mechanised facility, with conveyor belts, automated sorting and packing stations, walk-in coolers and the like. In mechanised harvesting, processing may also begin as part of the actual harvest process, with initial cleaning and sorting performed by the harvesting machinery. Initial post-harvest storage conditions are critical to maintaining quality. Each crop has an optimum range of storage temperature and humidity. Also, certain crops cannot be effectively stored together, as unwanted chemical interactions can result. Various methods of high-speed cooling, and sophisticated refrigerated and atmosphere-controlled environments, are employed to prolong freshness, particularly in large-scale operations. Regardless of the scale of harvest, from domestic garden to industrialised farm, the basic principles of post-harvest handling for most crops are the same: handle with care to avoid damage (cutting, crushin Inadequate attention to agriculture has led to steep rise in food prices and increased food riots. Food crisis has aggravated further because of climate change and diversion of arable lands to urbanization, industrialization and also for producing biofuel. The challenge to agriculture in coming years is immense (ICAR Vision, 2030).g, bruising), cool immediately and maintain in cool conditions, and cull (remove damaged items)

Apart from facing the challenge of increasing the food production in the country, the another challenge which the Indian farmers are facing is to reduce the losses of food grain which occurs at different stages of post harvest operations after harvesting till marketing of the produce. Post harvest handling is the stage of crop production immediately following harvest, including cooling, cleaning, sorting and packing. The instant a crop is removed from the ground, or separated from its parent plant, it begins to deteriorate. Post harvest treatment largely determines final quality, whether a crop is sold for fresh consumption, or used as an ingredient in a processed food product. The most important goals of post harvest handling are to keep the product cool, avoid moisture loss and slow down undesirable chemical changes and to avoid physical damage such as bruising, to delay spoilage. Sanitation is also an important factor to reduce the activities of pathogens that could be carried by fresh produce.

The extent to which deterioration and loss occur in storage depends on physical and production factor, the storage environment and biological factors. The loss is not merely in terms of quantity only but also in quality of the food grains. The qualitative loss is attributed to chemical changes in protein, carbohydrates, amino acid and vitamins which affect the nutritive value of grains. When damp, several biological agents like fungi, bacteria, insect and mites attack the grains. The common micro-organisms responsible for damage are Aspergillums and Penicillium. The food grains attacked by insect not only become unfit for human consumption but even if it is used for seed purpose, it losses its germination power.

The post harvest management and loss prevention of food grains is prime responsibility of farm women as the operations like winnowing, drying and storage of produce are predominately done by them. Due to illiteracy and lack of scientific knowledge million tones food grains are either damaged or lost. Although intensive efforts have been made by the Government for 
dissemination of technologies related to post harvest however, there is conspicuous sex bias in extension and training programmes of women. The bias is so deeply rooted that in areas where women's participation is almost monopoly like winnowing, drying, storage and processing of grains etc., the men are being trained. The result is that women is totally ignored and unaware about scientific methods of post harvest and are bound to use traditional practices which are passed from generation to generation. In order to minimize the post harvest losses there is utmost need to educate the farm families especially women about scientific methods of grain storage to enable them to make the maximum use of available produce in term of quality and quantity.

Generally, losses in cereals and pulses during the post-harvest operations amount to about 810 per cent of field production (Hand book of Agriculture, 2011). Hence, in order to improve agriculture situation in the country the special attention has to be given towards minimization of post harvest losses.

\section{Materials and Methods}

The present study was conducted in the Agroclimatic zone IV A i.e. Sub- humid Southern Plain and Aravali Hills of Rajasthan State. Zone IV A covers all the tehsils of Bhilwara and Rajsamand districts, all tehsils of Udaipur district except Dhariyawad, Salumber and Sarada, all tehsils of Chittorgarh district and Aburoad and Pindwara tehsils of Sirohi district. Out of these, two districts namely Udaipur and Chittorgarh were selected purposively on the basis of highest production of maize. Zone IV- A of Rajasthan covers fourteen panchayat samities of Udaipur and eleven of Chittorgarh district. Out of these, two panchayat samities from each district were selected purposively on the basis of highest production of maize. Thus, from Udaipur district, Mavli and Girwa panchayat samities and from Chittorgarh district, Begu and Chittorgarh panchayat samities were selected. In each district, panchayat samiti wise list of villages was prepared and from the list three villages from each panchayat samiti were selected on random basis. Thus, there were six villages from each district making total 12 villages from both the districts.

For selection of sample, a comprehensive list of maize growers was prepared from each identified village with the help of village Patwari and Agricultural Supervisor of the respective village and was categorized as small, marginal and large farmers on the basis of land holding. From each category, five farm families were selected from each village on random basis. Thus, there were 15 farm families from each village and 90 farm families from each district. One male and one female member of the farm family who was actively involved in maize cultivation was included in the sample. Thus, total sample for the present study was 360 respondents (180 farmers and 180 farm women).

\section{Results and Discussion}

\section{Constraints in adoption of post harvest technologies of maize}

Table 1 presents information about constraints faced by the maize growers in adoption of post harvest technologies. Perusal of the table shows that "non availability of fumigants in time" was expressed as an important constraint and ranked I by the farm families with MPS 50.83. "Lack of knowledge about improved storage structure" and "lack of knowledge about recommended fumigants" were the constraints faced with MPS 37.50 and 31.94 and rank II \& III, respectively. Farm families also experienced the problem of fear in use of rodenticides and fumigants due to its toxicity with MPS 26.67 and 25.83 and rank IV \& V, respectively. 
Table.1 Constraints faced by farmers and farm women regarding post harvest technologies of Maize

\begin{tabular}{|c|c|c|c|}
\hline S. No. & Post Harvest Constraints & MPS & Rank \\
\hline 1 & Non availability of fumigants in time & 50.83 & I \\
\hline 2 & Lack of knowledge about improved storage structure & 37.50 & II \\
\hline 3 & Lack of knowledge about recommended fumigant & 31.94 & III \\
\hline 4 & Fear in use of rodenticides due to its poisonous nature & 26.67 & IV \\
\hline 5 & Fear in use of fumigant due to its toxicity & 25.83 & V \\
\hline 6 & Lack of knowledge about rodenticides & 23.89 & VI \\
\hline 7 & Unaware about place of availability of fumigants & 23.06 & VII \\
\hline 8 & High cost of storage structure & 18.6 & VIII \\
\hline \multirow[t]{2}{*}{9} & Doubt about effectiveness of rodenticides & 13.89 & IX \\
\hline & Overall & 27.96 & \\
\hline
\end{tabular}

The farm families expressed that they were not using rodenticides and fumigants due to its poisonous nature.

Some of the farmers also faced problems of "lack of knowledge about rodenticides" and "unaware about place of availability of fumigants" with MPS 23.89 and 23.06 and rank VI and VII, respectively. High cost of storage structure was the another problem experienced by the farmers with MPS 18.06 and rank VIII.

Some of the farm families were not convinced about the effectiveness of rodenticides for rat control and expressed that many a times the zinc phosphide used for rat control is not effective in controlling the rats.

The findings are in line with Sharma (2005) revealed that high cost of improved storage structures, lack of knowledge and exposure to trainings related to PHT, lack of knowledge regarding place of availability of fumigants and rodenticides were the major constraints faced by the respondents in adoption of improved post harvest technologies of wheat and bajra.

\section{References}

Handbook of Agriculture.2011.Published by Directorate of Knowledge Management in Agriculture, ICAR, New Delhi-110 012.

ICAR Vision 2030.2011. Retrieved from www.icar.org.in/files/ICAR.vision2030.Pdf on October 22nd, 2013.

Jideani, Afam I.O.; Anyasi, Tonna A.; Mchau, Godwin R.A.; Udoro, Elohor O.; Onipe, Oluwatoyin O. (13 September 2017). "Processing and Preservation of FreshCut Fruit and Vegetable Products". Postharvest Handling. InTech. doi:10.5772/intechopen.69763.

Janet Bachmann and Richard Earles (August 2000). "Postharvest Handling of Fruits and Vegetables". NCAT. Archived from the original on 2002-02-11.

\section{How to cite this article:}

Chamandeep Kaur, Dhriti Solanki and Choudhary, L. R. 2019. Constraints in Adoption of Post Harvest Technologies in Maize Crop Faced by Farm Families of Udaipur and Chittorgarh District of Rajasthan, India. Int.J.Curr.Microbiol.App.Sci. 8(12): 429-432.

doi: https://doi.org/10.20546/ijcmas.2019.812.057 